\title{
THE IMPACT OF PHYSICIAN INTERVENTION AND TOBACCO CONTROL POLICIES ON AVERAGE DAILY CIGARETTE CONSUMPTION AMONG ADULT SMOKERS
}

\author{
John A. Tauras \\ Lan Liang \\ Working Paper 9790 \\ http://www.nber.org/papers/w9790 \\ NATIONAL BUREAU OF ECONOMIC RESEARCH \\ 1050 Massachusetts Avenue \\ Cambridge, MA 02138 \\ June 2003
}

\begin{abstract}
We are grateful to Gary Giovino and ImpacTeen for providing the clean indoor air laws and to Matthew Farrelly and Terry Pechacek for providing the state tobacco control spending data. We would also like to thank Tomas Rinkunas and Stavros Tsipas for excellent research assistance. The views expressed herein are those of the authors and not necessarily those of the National Bureau of Economic Research.

(C)2003 by John A. Tauras and Lan Liang. All rights reserved. Short sections of text not to exceed two paragraphs, may be quoted without explicit permission provided that full credit including (C) notice, is given to the source.
\end{abstract}


The Impact of Physician Intervention and Tobacco Control Policies on Average Daily Cigarette Consumption Among Adult Smokers

John A. Tauras and Lan Liang

NBER Working Paper No. 9790

June 2003

JEL No. I1

\begin{abstract}
Physicians' advice to stop smoking has been found to increase smoking cessation rates in controlled clinical trials. However, these finding may not be applicable under real world conditions. This paper investigates the impact of physicians' advice and tobacco control policies on conditional cigarette demand among adults employing non-experimental data. Because the data is non-experimental, the variables reflecting physician advice to stop smoking and cigarette consumption are likely to be endogenous. We implement a three stage least squares regression technique designed to take account the joint determination of physician advice and cigarette smoking. The results from these models imply that smokers that received advice from their physician to quit smoking will decrease their average daily consumption by between 5-6 cigarettes per day as compared to smoker who do not receive advice. This result implies that physicians' advice is effective in curtailing smoking in real world settings. Other policies that were found to decrease average smoking by smokers include: the real price of cigarettes and clean indoor air laws.
\end{abstract}

John A. Tauras

Department of Economics

University of Illinois at Chicago

601 S. Morgan Street

Chicago, IL 60607-7121

and NBER

tauras@uic.edu

\section{Lan Liang}

Department of Economics

University of Illinois at Chicago

601 S. Morgan Street

Chicago, IL 60607-7121

and NBER

lliang@uic.edu 


\section{Introduction}

Cigarette smoking is the single most preventable cause of death and disability in the United States, responsible for more than 400,000 premature deaths each year (CDC, 1999). Despite the deleterious health effects of cigarette smoking, approximately 47.2 million adults in the United States (U.S.) aged 18 and over were current smokers in 1998, representing nearly one quarter $(24.1 \%)$ of the total U.S. adult population (CDC, 2000).

In this paper, we examine the impact of physician advice, cigarette prices, clean indoor air laws, and state tobacco control spending on the average number of cigarettes smoked by adult smokers in the United States. It is well established in the medical literature that physicians acting as educators and facilitators can have a significant effect on the smoking behavior of their patients (Fiore et al., 1996; Manley, et al., 1991; Kottke, et al., 1988; Ockene and Zapka, 1997). The efficacy of physician intervention is important because more than $70 \%$ of smokers in the United States have some contact with a physician each year (Davis, 1988; USDHHS, 1994). Several studies have concluded that a positive relationship exists between the amount of time a physician spends counseling their patients and the probability of successful smoking cessation (Wilson, et al, 1988; Ockene, et al, 1991). Moreover, several studies have found that additional intervention modalities, such as reminder systems, increase the likelihood of successful cessation (Cohen, et al. 1989; Ockene, et al. 1991; Wilson, 1988). The aforementioned findings from the medical literature, however, generally come from controlled clinical trials. The effect of physician advice in real world settings has yet to be quantified. 
Numerous econometric studies on the determinants of adult cigarette demand have been published over the past three decades. A vast majority of these studies have found a strong inverse relationship between cigarette prices or excise taxes and cigarette consumption. ${ }^{1}$ Some of these studies have employed individual level data to investigate adult cigarette demand. The use of individual level data allows researchers to investigate the impact of individual specific factors, such as physician counseling, on smoking behavior. In general, the studies that employ individual level data find cigarette prices and excise taxes to have a negative impact on adult cigarette demand (Lewit and Coate, 1982; Chaloupka, 1991; Chaloupka, 1992; Hu, et al, 1995; Ohsfeldt et al., 1999; Tauras, 2003a; Tauras, 2003b).

To our knowledge, only one published econometric study, conducted by Jones (1994), has examined the impact of medical advice on smoking behavior. While Jones (1994) did not control for cigarette prices or other tobacco control policies, he made a significant contribution to the literature by modeling smoking cessation as a function of medical advice. Jones includes both medical advice from a physician and medical advice from anyone else in his smoking cessation equations. Although Jones (1994) found physician advice to be positively associated with smoking cessation, he found the overall impact of medical advice to have an anomalous negative effect on smoking cessation.

Econometric studies of cigarette demand have the benefit of employing nonexperimental (i.e. non clinical trial) data in their analysis and are able to shed some light on the impact of physician advice on smoking behavior in a real world setting. However,

\footnotetext{
${ }^{1}$ For a comprehensive review of these studies see F.J. Chaloupka and K.E. Warner, "The Economics of Smoking" in The Handbook of Health Economics (North-Holland, Elsevier Science, 2000) and the various Surgeon General's reports (USDHHS, 1989, 1994, and 2000).
} 
since the data are not taken from a controlled clinical trial in which individuals are randomly assigned to either a treatment or control group, advice provided by physicians is likely to be endogenous. That is, it may be the case that physicians are more likely to provide information on the health hazards of smoking or more likely to advise individuals to cut back or quit smoking to individuals who smoke more on average or exhibit a smoking related illness.

We are not aware of any previous econometric studies that have examined the impact of medical advice on average cigarette consumption among smokers. Our study proposes to address this deficiency in the literature by providing the first examination of the impact of physician advice on cigarette demand among adult smokers while at the same time controlling for cigarette prices, tobacco control policies, and a variety of socioeconomic and demographic characteristics. Due to data limitations, we are not able to explore the impact of physician advice on actual smoking cessation attempts. In particular, only smokers are asked about whether or not they visited a physician and whether or not the physician advised them to quit smoking.

\section{Methodology}

\section{Theoretical Background}

The empirical models of cigarette smoking are based on the economic theory of demand. In order to derive cigarette demand equations, an individual's utility function must first be assumed. This utility function has cigarettes, other goods, and tastes as arguments. An individual maximizes his or her utility subject to a budget constraint, which is comprised of the price of cigarettes, income, and the prices of all other goods. This constrained maximization yields demand functions for cigarettes. The demand 
functions show that cigarette consumption is related to the price of cigarettes, prices of related goods, income, and individual's tastes.

Physicians' advice to stop smoking and tobacco control policies affect cigarette demand through what economists call the "full price" of cigarettes. The "full price" of cigarettes for adults includes not only the monetary price to purchase cigarettes, but also the costs associated with consuming cigarettes. Therefore, any policy that increases the monetary price of cigarettes (for example, increased excise taxes) or raises the expected costs associated with consumption (for example, physicians' advice, clean indoor air regulations, and increased anti-smoking sentiment) will increase the "full" price of cigarettes. According to the law of demand, as the "full" price of a good rises, the quantity demanded of that good decreases.

\section{Data}

The data that are employed in this study are taken from the September 1992, January 1993, May 1993, September 1995, January 1996, May 1996, September 1998, January 1999, and May 1999 Tobacco Use Supplements to the Current Population Survey (CPS), conducted by the Bureau of Labor Statistics of the U.S. Census Bureau. The CPS is a monthly survey of approximately 50,000 households that has been conducted for more than fifty years. Representing the civilian non-institutional population, the CPS focuses on labor force characteristics of the U.S. including employment, occupation, economic status, earnings, hours worked, and other indicators. During September 1992, additional questions regarding tobacco use were asked of all adult respondents as part of the Tobacco Use Supplement to the September 1992 CPS. Similar questions regarding tobacco use were repeated in the later Tobacco Use 
Supplements mentioned above. The sample employed in this study consists of a total of 90,790 current adult smokers who visited a physician within one year of being surveyed. Of those who visited a physician, 49,978 (55.05\%) received advice from their physician to quit smoking. Descriptive statistics of the variables can be found in Table 1.

Of particular importance to this research is the information collected on smokers' intensity of smoking. For each respondent in the sample, a variable reflecting the average number of cigarette smoked daily was created. Of equal importance is the information collected on physician advice. For each respondent, a dichotomous indicator of physician advice was created. This indicator takes on a value of one if the respondent's physician advised him/her to quit smoking and is equal to zero otherwise.

Based on the survey data, numerous independent variables are constructed to control for other factors thought likely to affect cigarette demand. These factors included: the age of the respondent in years; gender (male and female-reference category); family income in 1982-1984 dollars; indicators of race/ethnicity (African American, Asian, Native American, Black Hispanic, White Hispanic, other Hispanic, other race, and Caucasian-reference category); indicators of education (less than high school graduate, vocational school graduate, at least some college, college graduate, and high school graduate-reference category); indicators of marital status (married spouse present, married spouse absent, widowed, divorced, separated, and single - reference category); indicators of metropolitan living (lives within metropolitan area, metropolitan area not identified, and does not live in metropolitan area - reference category); and previous week employment status indicators (employed not at work, unemployed, not in the labor force, employed at work - reference category). 
In addition, to account for unobserved seasonal and regional heterogeneity, indicators of U.S. Census Bureau divisions the respondent resides (New England, Mid Atlantic, East North Central, West North Central, South Atlantic, East South Central, West South Central, Mountain, and West - reference category) and indicators of season of data collection (May, September, January - reference category) are created from the surveys.

Using state identifiers, we merged several tobacco control variables with the survey data. Cigarette price data were obtained from the annual Tax Burden on Tobacco. Until 1999, the Tobacco Institute published state level cigarette prices as of November 1. Since then, Orzechowski and Walker have published the data. These prices are weighted averages for a pack of 20 cigarettes based on the prices of single packs, cartons, and vending machine sales where the weights are the national proportions of each type of sale. These prices are inclusive of state level sales taxes applied to cigarettes but are exclusive of local cigarette taxes. Because the price published is as of November 1 of each year and because the dependent variable is based on past month smoking, we created a weighted average price for each quarter of each year. The average quarterly price was computed by subtracting state and federal excise taxes from the current year's price and the previous year's price and weighting the pre-tax prices accordingly. Then the average federal tax and average state tax for each quarter of the year were added to the quarterly average pretax price. To account for changes in the relative price of cigarettes over time, all cigarette prices were deflated by the national Consumer Price Index published by the Bureau of Labor Statistics (1982-1984=100). 
Using state identifiers, we also merged real state level per capita expenditure on tobacco control with the survey data. This variable was created by combining real per capita state specific excise tax funding and other state appropriated funds earmarked for tobacco control programs with real per capita non governmental state-level expenditures and per capita tobacco control expenditures from the following national programs: Americans' Stop Smoking Intervention Study program (ASSIST), Initiatives to Mobilize for the Prevention and Control of Tobacco Use (IMPACT), SmokeLess States, and the Association of State and Territorial Health Officials (ASTHO). Unfortunately, no information is available on what types of tobacco control interventions each program utilizes and how much is spent on each intervention. Thus, the overall state per capita tobacco control expenditure variable reflects total resources allocated toward tobacco control in each state.

Based on state identifiers, we also merged clean indoor air laws with the survey data. Six separate dichotomous indicators representing any restriction on smoking in private worksites, restaurants, shopping malls, health facilities, public transit facilities, and grocery/retail stores were created. In addition, to capture the overall magnitude of each state's clean indoor air legislation and to decrease the collinearity associated with including highly correlated state level policies, a clean indoor air index variable was merged with the surveys. The index variable employs the 6 aforementioned clean indoor air restrictions, however, each restriction is now allowed to take on a value of between 0 and 3 depending on the strength of protection. That is, if smoking is prohibited, the restriction rating is 3 ; if smoking is restricted with separate ventilation, the restriction rating is 2 ; if smoking is restricted with no separate ventilation the restriction rating is 1 ; 
and if smoking is not restricted, then the restriction rating is 0 . The index is derived by adding up the equally weighted restriction ratings for each of the six restrictions.

We also merged in state-level laws related to youth tobacco access including: minimum age required to purchase cigarettes, separate dichotomous indicators for states that restrict youth's from possessing, using, and purchasing cigarettes, a dichotomous indicator that restricts cigarette vending machine sales to adult only locations with strict adult supervision, and a dichotomous indicator for state's that have created a statewide enforcement authority to prevent cigarette sales to minors, a dichotomous indicator for states that require clerks to ask for photo identification from anyone who does not look at least 21 year of age, and a dichotomous indicator for states that will suspend or revoke an outlets tobacco license for selling cigarettes to minors.

\section{Empirical Methods}

Because the data that is employed in this analysis is non-experimental, the variables reflecting physician advice to stop smoking and cigarette consumption are likely to be endogenous. That is, the number of cigarettes a smoker consumes and whether or not a physician provides advice are likely jointly determined. In particular, physicians' advice is likely to influence the number of cigarettes consumed by smokers while at the same time the number of cigarettes smoked by smokers is likely to influence whether or not a physician provides advice. In addition, it is possible that important factors that influence physician advice may be unobservable and these factors may be related to the error term in the cigarette demand equation. Likewise, it is possible that factors that influence cigarette demand are unobservable and these factors may be related to the error term in the physician advice equation. 
In this paper we estimate the following two equation simultaneous equation structural model:

$$
\begin{aligned}
& C=\alpha_{0}+\alpha_{1} A+\alpha_{2} P+\alpha_{3} T C_{A}+\alpha_{4} X+\alpha_{5} R+\alpha_{6} S+u_{1} \\
& A=\beta_{0}+\beta_{1} C+\beta_{2} T C_{Y}+\beta_{3} T C_{A}+\beta_{4} R+u_{2}
\end{aligned}
$$

where $C$ is the average number of cigarettes consumed daily by smokers, $A$ is a dichotomous indicator of physician advice, $P$ is the price of cigarettes, $T C_{A}$ is a vector of tobacco control policies affecting adults, $X$ is a vector of individual characteristics that are likely to influence cigarette use, $T C_{Y}$ is a vector of youth tobacco control policies, $R$ and $S$ are region and season fixed effects, respectively, and $u_{1}$ and $u_{2}$ are error terms that capture unobservable influences on cigarette consumption and physician advice, respectively. It is important to note that equation (1) is a behavior equation for smoker while equation (2) is a behavioral equation for physicians yielding a ceteris paribus causal relationship.

The joint determination of $C$ and $A$ suggests a correlation between $u_{1}$ and $u_{2}$, resulting in a correlation between $A$ and $u_{1}$ in equation (1) and a correlation between $C$ and $u_{2}$ in equation (2). The correlation between $u_{1}$ and $u_{2}$ results in endogeneity bias if conventional (non instrumental variable) methods are applied to the estimation of equations (1) and (2).

We employ a three stage least squares (3SLS) estimator to model the simultaneous equation system. In the first step of 3SLS, each endogenous variable ( $C$ and $A)$ is regressed on all the exogenous variables from both equations $\left(P, T C_{A}, X, T C_{Y}\right.$, 
$S$, and $R$ ) using ordinary least squares techniques. ${ }^{2}$ The predicted values from these regressions are used as instruments for the endogenous variables. In the second step, the residuals from a two-stage least squares regression of both structural equations is employed to obtain consistent estimates of the variance-covariance matrix of the structural equations' disturbances. Finally, in the third step, Generalized Least Squares estimation employing the variance-covariance matrix estimated in stage 2 and the instruments developed in stage 1 is performed. For a complete discussion, see Zellner and Theil (1962).

Since equation (1) is of most interest, it is important to discuss the exclusion restrictions of this equation. In particular, it is assumed that tobacco control policies that affect only youth (minors) influence the probability of physicians providing advice to patients, but are not direct determinants of conditional cigarette demand among adults (non-minors). This specification of adult cigarette demand is consistent with previous economic research that omits youth tobacco laws when estimating adult demand equations. Equation (2) also implies a set of exclusion restrictions. In particular, once the amount of cigarette consumed and unobserved regional factors, such as tobacco sentiment, are controlled for, individual characteristics and seasonality are assumed to have no direct affect on physicians' decisions to provide advice.

III. Results

Table 2 presents the results from several alternative specifications. Model 1 employs separate ordinary least squares (OLS) equations for conditional cigarette

\footnotetext{
${ }^{2}$ Note: Given the large sample size that is employed, the linear probability model used to estimate physician advice (a binary dependent variable) yields very similar results to non-linear probability models such as logit and probit methods.
} 
demand and physician advice that do not account for endogeneity. The determinants of cigarette demand include: physician advice, real cigarette price, real per capita expenditure on tobacco control, six dichotomous clean indoor air restrictions, education, family income, gender, race, age, marital status, metropolitan status, employment, and seasonality and region fixed effects. The determinants of physician advice include: average daily cigarette consumption, nine separate laws that restrict the availability of cigarettes to minors, real per capita expenditure on tobacco control, six dichotomous clean indoor air restrictions, and region fixed effect to account for unobserved regional heterogeneity in anti-smoking counseling of physicians.

Models 2 and 3 employ Three Stage Least Squares methods to model the simultaneous equation system. Model 2 contains the same regressors as Model 1 to estimate the conditional demand and physician advice equations, whereas Model 3 replaces the six dichotomous clean indoor air restrictions with a clean indoor air index variable, but is otherwise the same as Model 2. Model 3 is designed to capture the overall magnitude of clean indoor air laws on cigarette demand and minimizes the collinearity resulting from the inclusion of a group of highly correlated measures of clean indoor air restrictions.

The model that ignores the endogeneity of physician advice results is a counterintuitive impact of physician advice on adult cigarette demand. That is, in Model 1, physician advice to stop smoking is found to have a positive and highly significant impact on the average number of cigarettes smoked by smokers. In both models that correct for endogeneity, physician advice to stop smoking has the a priori expected negative sign and significance. 
To confirm that physician advice is in fact endogenous we estimate a reduced form equation of physician advice and obtain the residuals. We then add the reduced form residuals to the structural cigarette demand equation and test for the significance of the residuals using ordinary least squares methods. As suspected the residuals are highly significant implying that physician advice is indeed endogenous. A similar procedure was employed to evaluate the endogeneity of daily smoking intensity in equation (2). The residuals from a reduced form smoking intensity equation were found not to be statistically significant from zero at conventional levels when added to the physician advice structural equation. Although this is not a surprising finding given the similarities in the smoking intensity coefficients between the OLS and Three Stage Least Squares physician advice equations. Because exogeneity of physician advice is rejected, the remainder of the paper will focus on the results of Models 2 and 3.

Given that the simultaneous equation systems are identified through exclusion restrictions, it is important to make sure that we have identified important determinants of physician advice and smoking intensity in the first stage regressions. We use Wald tests to check the null hypotheses that the set of excluded variables are simultaneously equal to zero in the first stage regressions. As you will recall 8 dichotomous tobacco control policies that affect only minors are excluded from the adult cigarette demand equations. A Wald test supports the joint significance of these eight youth smoking laws in the first stage regression of physician advice. The Wald statistics distributed chi-squared with 8 degrees of freedom are significant at better than the .0001 level in both Models 2 and 3 . Similarly, as you will recall, individual characteristics, seasonality, and price are excluded from the physician advice equations. A Wald test checks the joint significance 
of these variables in the first stage regressions of smoking intensity. The Wald statistics distributed chi-squared with 27 degrees of freedom are significant at better than the .0001 level in both Models 2 and 3. The results from the first stage regressions of physician advice and smoking intensity are presented in Table 3.

\section{Conditional Cigarette Demand Results}

The simultaneous equation results support the hypothesis that physician advice to quit smoking decreases average smoking among individuals who continue to smoke. The finding that physicians' advice is inversely related to smoking is consistent with the medical literature from controlled clinical trial, and more importantly, suggests that physicians' advice to quit smoking is effective in reducing cigarette consumption in real world settings. Our findings imply that holding other determinants of demand constant, smokers whose physicians advise them to quit smoking smoke between 5.74 and 5.97 fewer cigarettes a day than smokers who do not receive advice from a physician to quit smoking. Given that the average number of cigarettes smoked among smokers in our sample is 16.89 , our results imply that physicians advice to quit smoking decreases the average number of cigarettes consumed daily by smokers by approximately one-third.

The real price of cigarettes is found to have a negative and statistically significant impact on the average number of cigarettes smoked by smokers. The estimated price elasticity of conditional cigarette demand for Models 2 and 3 are -0.142 and -0.112 , respectively. These estimates imply that a $10 \%$ increase in the real price of cigarettes would decrease the average amount of cigarettes consumed by adult smokers by between $1.1 \%$ and $1.4 \%$. The estimated conditional demand elasticities are consistent with those

found in other studies of adult smokers. For example, Lewit and Coate (1982) and Evans 
and Farrelly (1998) estimated average conditional price elasticities for adults of -0.103 and -0.117 , respectively.

Laws that restrict smoking in private worksites and public transportation have a negative and significant impact on average daily smoking among adult smokers.

However, laws that restrict smoking in health facilities, restaurants, grocery/retail stores, and shopping malls seem to have an anomalous positive impact on the conditional demand of smokers. It is plausible that the anomalous estimates are a result of the clean indoor air laws being highly correlated with one another. The clean indoor air laws that are employed in this study are enacted at the state level and it is likely that when states implement or enhance tobacco control programs they enact several clean indoor air restrictions at the same time. In an attempt to assess the magnitude of the collinearity, each of the clean indoor air laws was regressed on the remaining clean indoor air laws and the region fixed effects using ordinary least squares methods. The coefficients of determination from these regressions implied that $70 \%, 64 \%, 58 \%, 49 \%, 43 \%$, and $41 \%$ of the variation in grocery store laws, restaurant laws, private workplace laws, shopping center laws, health facility laws, and transportation laws, respectively, could be explained by the remaining smoke free air laws and region dummies. These results suggest that moderate collinearity exists and is likely impacting the results.

In an attempt to examine the overall impact of clean indoor air laws on adult conditional demand and to mitigate the collinearity of including correlated regressors, Model 3 replaces the dichotomous clean indoor air indicators with the clean indoor air index variable described above. The index variable has a negative and significant impact on average daily consumption among adults. These results clearly indicate that more 
comprehensive smoke-free air laws will decrease the average number of cigarettes smoked by adult smokers.

Real state-level per-capita spending on tobacco control programs is found to have an insignificant impact on conditional cigarette demand among adults in Models 2 and 3. Although this finding does not adhere to our a priori expectation, the results are quite plausible given that a large proportion of these funds are used for youth smoking prevention.

Briefly reviewing the estimates for the other independent variables included in the conditional cigarette demand equations: Smokers who live in the Western census division smoke significantly less per day than the remaining 8 divisions, accept for the Mountain division in Model 3 which is not significant; Smokers smoke statistically fewer cigarette per day on average in January as compared to May and September - this is consistent with many smokers making attempts to quit or decrease the quantity of cigarettes smoked as part of a New Year's Resolution; A strong inverse relationship if found between education and average quantity smoked among smokers; Smokers with higher family incomes smoke less on average than smokers with lower family incomes. This suggests that smoking is an economically inferior behavior; Smokers who reside in metropolitan areas smoke fewer cigarettes than do smokers in non metropolitan areas; Age and conditional smoking are positively related; Smokers who are divorced, separated, or married smoke more on average than do single smokers; Male smokers smoke more than female smokers; Caucasians smokers smoke more on average than smokers from any other racial group; Smokers who are unemployed, not in the labor force, or absent from 
work in the prior week smoke more on average than smokers who worked in the prior week.

\section{Physician Advice Results}

The simultaneous equation results support the hypothesis that physicians are significantly more likely to advise smokers who smoke more on average to quit smoking than smokers who smoke fewer cigarettes per day.

In general, physicians who practice in states that have stronger youth tobacco laws are more likely to advise their patients who smoke to quit smoking. That is, physicians are more likely to advise their patients who smoke to quit in states that have: established an agency to address youth tobacco consumption; implemented purchase, possession, and use laws; have established higher minimum purchase age requirements; and require photo identification of individual who look at least 21 years old ${ }^{3}$.

Physicians who practice in states that spend more per capita on comprehensive tobacco control programs are significantly more likely to advise their patients to quit smoking than are physicians who practice in states that spend less per capita on tobacco control. Given the estimated strong inverse relationship between physician advice and average smoking, these results imply that states that spend more per capita on tobacco control have an indirect impact on adult smoking through physicians' advice.

Individually, the dichotomous clean indoor air laws are found not to be statistically different from zero at the $5 \%$ level of a two-tailed test when predicting physician advice. However, when the extent of each restriction is taken into account and

\footnotetext{
${ }^{3}$ Note: minor purchase law is only significant at the $11 \%$ significance level (two-tail) in Model 2 and the minimum purchase age is significant at $8 \%$ significance level (two tail) in Model 3.
} 
aggregated into an index variable, the overall magnitude of clean indoor air laws is found to have a positive and significant impact of physician' delivering smoking cessation advice to smokers.

With respect to regional differences in physicians providing advice, physicians who practice in the New England, Mid Atlantic, and East North Central divisions are more likely to provide advice to quit smoking than physicians who practice in the Western division ${ }^{4}$. Moreover, physicians who practice in the West North Central, East South Central, West South Central, and Mountain divisions are less likely to advise their patients to quit than physicians who practice in the Western division. ${ }^{5}$

\section{Discussion}

Physicians' advice to stop smoking has been found to increase smoking cessation rates in controlled clinical trials. However, these finding may not be applicable under real world conditions. In fact, the only published study, that we are aware of, that examined the impact of physicians' advice on smoking behavior that employed nonexperimental data found medical advice not to be a strong predictor of smoking cessation (Jones, 1994).

Our paper attempts to inform the debate by using non-experimental data to estimate the impact of physicians' advice on the conditional cigarette demand of adults. Physician advice was found to be an endogenous explanatory variable, and if the endogeneity was not controlled for, anomalous results were found. That is, physicians' advice has a positive and highly significant impact on the average number of cigarettes

\footnotetext{
${ }^{4}$ Note: Mid Atlantic is only significant at the $10 \%$ significance level (two-tail test) in Model 2.

${ }^{5}$ Note: Mountain is only significant at the $10 \%$ significance level (one-tail test) in Model 3.
} 
smoked by smokers. When we control for endogeneity using a simultaneous equation system, physician advice is found to have a negative and significant impact on average smoking by adult smokers. The results from these models imply that smokers who continue to smoke that received advice from their physician to quit smoking will decrease their average daily consumption by between 5-6 cigarettes per day as compared to smoker who do not receive advice. Other policies that were found to decrease average smoking by smokers include: the real price of cigarettes (which can easily be increased through the use of cigarette excise taxes) and clean indoor air laws. 


\section{References}

Centers for Disease Control and Prevention: Cigarette Smoking among Adults - United States, 1998. Morbidity and Mortality Weekly Report, v49 n39: 881-884, 2000.

Centers for Disease Control and Prevention's Tobacco Information and Prevention Sourcepage, "Adult Prevalence Data", Centers for Disease Control and Prevention, 1999

Cohen, S., G. Stokey, B. Katz, C. Drook, and A. Smith, "Encouraging Primary Care Physicians to Help Smokers Quit,” Annals of Internal Medicine, Vol. 110, no. 8, 1989.

Davis, R.M., "Uniting Physicians Against Smoking: The Need for a Coordinated National Strategy,” JAMA, Vol. 259: pp. 2900-1, 1988.

Evans, W.N. and M. C. Farrelly, " The Compensating Behavior of Smokers: Taxes, Tar, and Nicotine," Rand Journal of Economics, Vol. 29, No. 3, 1998.

Fiore, M.C., W.C. Baily, S.J. Cohen, et al., Clinical Practice Guidelines No. 18 Smoking Cessation. Rockville, MD: U.S. Department of Health and Human Services, U.S. Public Health Service, Agency for Health Care Policy and Research, a996 (AHCPR Publication \# 96-0692).

Hu, T.W., Q.F. Ren, T.E. Keeler, and J. Bartlett, "The Demand for Cigarettes in California and Behavioural Risk Factors," Health Economics, Vol. 4, No. 1, 1995.

Jones, A.M., "Health, Addiction, Social Interaction, and the Decision to Quit Smoking," Journal of Health Economics, Vol. 13, 1994.

Kottke, T.E., "R. Battista, G. DeFriese, and M. Breek, "Attributes of Successful Smoking Cessation Interventions in Medical Practice. A Meta-Analysis of 39 Controlled Trials. JAMA, Vol. 259 pp. $2882-9$

Manley, M., R. Epps, C. Husten, T Glynn, D. Shopland, "Clinical Interventions in Tobacco Control: A National Cancer Institute Training Program for Physicians," JAMA, Vol. 268(22).

Ohsfeldt, R.L., R.G. Boyle, and E. Capilouto, "Tobacco Taxes, Smoking Restrictions, and Tobacco Use," in: The Economic Analysis of Substance Use and Abuse: An 
Integration of Econometric and Behavioral Economic Research, edited by Frank Chaloupka, Michael Grossman, Warren Bickel, and Henry Saffer, University of Chicago Press, 1999.

Okene, J.K., J. Kristeller, R. Goldberg, D. Hosmer, T. Amick, and K. Kalan, "Increasing the Efficacy of Physician-Delivered Smoking Intervention: A Randomized Clinical Trial, Journal of General Internal Medicine, Vol. 9, 1991.

Okene, J.K. and J.G. Zapka, "Physician Based Smoking Intervention: A Rededication to a Five Step Strategy to smoking Research," Addictive Behaviors, Vol. 22, No. 6, 1997.

USDHHS, "Current Estimates From the National Health Interview Survey, 1993 (DHHS Publication \# PHS 95-1518). Hyattsville, MD: Public Health Service, Centers for Disease Control, National Center for Health Statistics, 1994.

Tauras, J.A. "An Empirical Analysis of Adult Cigarette Demand,” Eastern Economic Journal, Forthcoming, 2003.

Tauras, J.A. "Public Policy and Some-day Smoking Among Adults," Journal of Applied Economics, Forthcoming, 2003.

Wilson, D., W. Taylor, R. Gilbert, J.A. Best, E.A. Lindsay, D.G. Willms, and J. Singer, "A Randomized Trial of a Family Physician Intervention for Smoking Cessation," JAMA, Vol. 260, No. 11, 1988. 


\section{Table 1}

\section{Descriptive Statistics}

\begin{tabular}{|c|c|c|}
\hline Variable & \multicolumn{2}{|c|}{ Sample Mean $(\bar{x})$ and Sample Standard Deviation $(s)$} \\
\hline Physician Advice & $\bar{x}=0.5505$ & $s=0.4974$ \\
\hline Price & $\bar{x}=1.3007$ & $s=0.2003$ \\
\hline Real Per-Capita Expenditure & $\bar{x}=0.0037$ & $s=0.0093$ \\
\hline Private Worksite & $\bar{x}=0.4427$ & $s=0.4967$ \\
\hline Health Facility & $\bar{x}=0.7953$ & $s=0.4035$ \\
\hline Public Transportation & $\bar{x}=0.8020$ & $s=0.3985$ \\
\hline Restaurants & $\bar{x}=0.6214$ & $s=0.4850$ \\
\hline Grocery/Retail stores & $\bar{x}=0.5738$ & $s=0.4945$ \\
\hline Shopping Malls & $\bar{x}=0.1200$ & $s=0.3249$ \\
\hline Clean Indoor Air Index & $\bar{x}=4.4977$ & $s=2.9963$ \\
\hline Cigarettes Per Day & $\bar{x}=16.8934$ & $s=11.3924$ \\
\hline Photo ID 21 & $\bar{x}=0.0764$ & $s=0.2656$ \\
\hline Suspend/Revoke License & $\bar{x}=0.2144$ & $s=0.4104$ \\
\hline Minimum Purchase Age & $\bar{x}=17.8084$ & $s=1.9954$ \\
\hline Purchase Law & $\bar{x}=0.5009$ & $s=0.5000$ \\
\hline Use Law & $\bar{x}=0.2583$ & $s=0.4377$ \\
\hline Possession Law & $\bar{x}=0.3534$ & $s=0.4780$ \\
\hline Vending Machine & $\bar{x}=0.0060$ & $s=0.0775$ \\
\hline State Authority & $\bar{x}=0.3189$ & $s=0.4660$ \\
\hline New England & $\bar{x}=0.0826$ & $s=0.2753$ \\
\hline Mid Atlantic & $\bar{x}=0.1346$ & $s=0.3413$ \\
\hline East North Central & $\bar{x}=0.1619$ & $s=0.3684$ \\
\hline West North Central & $\bar{x}=0.1031$ & $s=0.3041$ \\
\hline South Atlantic & $\bar{x}=0.1696$ & $s=0.3753$ \\
\hline East South Central & $\bar{x}=0.0578$ & $s=0.2333$ \\
\hline West South Central & $\bar{x}=0.0868$ & $s=0.2815$ \\
\hline Mountain & $\bar{x}=0.1031$ & $s=0.3041$ \\
\hline May & $\bar{x}=0.3151$ & $s=0.4645$ \\
\hline September & $\bar{x}=0.3586$ & $s=0.4796$ \\
\hline Education Less Than High School & $\bar{x}=0.1975$ & $s=0.3981$ \\
\hline Education Some College & $\bar{x}=0.2320$ & $s=0.4221$ \\
\hline Education at Least College Degree & $\bar{x}=0.1211$ & $s=0.3262$ \\
\hline
\end{tabular}




\begin{tabular}{|l|cc|}
\hline Variable & Sample Mean $(\bar{x})$ and Sample Standard Deviation $(s)$ \\
\hline Vocational School & $\bar{x}=0.0422$ & $s=0.2009$ \\
\hline Real Family Income & $\bar{x}=216.9199$ & $s=151.0216$ \\
\hline Metropolitan & $\bar{x}=0.7175$ & $s=0.4502$ \\
\hline Metropolitan Not Identified & $\bar{x}=0.0089$ & $s=0.0940$ \\
\hline Age & $\bar{x}=42.4886$ & $s=14.7383$ \\
\hline Married Spouse Present & $\bar{x}=0.5213$ & $s=0.4995$ \\
\hline Married Spouse Absent & $\bar{x}=0.0092$ & s $=0.0953$ \\
\hline Widowed & $\bar{x}=0.0624$ & $s=0.2418$ \\
\hline Divorced & $\bar{x}=0.1673$ & $s=0.3732$ \\
\hline Separated & $\bar{x}=0.0425$ & $s=0.2017$ \\
\hline Male & $\bar{x}=0.4158$ & $s=0.4929$ \\
\hline White Hispanic & $\bar{x}=0.0403$ & $s=0.1968$ \\
\hline Black Hispanic & $\bar{x}=0.0013$ & $s=0.0356$ \\
\hline Other Hispanic & $\bar{x}=0.0017$ & $s=0.0413$ \\
\hline African American & $\bar{x}=0.0928$ & $s=0.2902$ \\
\hline Native American & $\bar{x}=0.0160$ & $s=0.1254$ \\
\hline Asian & $\bar{x}=0.0152$ & $s=0.1225$ \\
\hline Other Race & $\bar{x}=0.0003$ & $s=0.0166$ \\
\hline Employed. But Did Not Work & $\bar{x}=0.0299$ & $s=0.1704$ \\
\hline Unemployed & $\bar{x}=0.0542$ & $s=0.2264$ \\
\hline Not in Labor Force & $\bar{x}=0.2963$ & $s=0.4566$ \\
\hline
\end{tabular}




\section{Table 2}

\section{OLS and Three Stage Least Squares Results}

\begin{tabular}{|c|c|c|c|c|c|c|}
\hline \multirow{3}{*}{ Variable } & \multirow{2}{*}{\multicolumn{2}{|c|}{$\begin{array}{c}\text { Ordinary Least Squares } \\
\text { Model } 1 \\
\end{array}$}} & \multirow{2}{*}{\multicolumn{2}{|c|}{$\begin{array}{c}\text { Three Stage Least Squares } \\
\text { Model } 2\end{array}$}} & \multicolumn{2}{|c|}{ Three Stage Least Squares } \\
\hline & & & & & & \\
\hline & $\begin{array}{l}\text { Conditional } \\
\text { Cigarette } \\
\text { Demand }\end{array}$ & $\begin{array}{l}\text { Physician } \\
\text { Advice }\end{array}$ & $\begin{array}{l}\text { Conditional } \\
\text { Cigarette } \\
\text { Demand }\end{array}$ & $\begin{array}{l}\text { Physician } \\
\text { Advice }\end{array}$ & $\begin{array}{l}\text { Conditional } \\
\text { Cigarette } \\
\text { Demand }\end{array}$ & $\begin{array}{c}\text { Physician } \\
\text { Advice }\end{array}$ \\
\hline Physician Advice & $\begin{array}{l}2.9415 \\
40.83\end{array}$ & & $\begin{array}{c}-5.9743 \\
-2.84\end{array}$ & & $\begin{array}{c}-5.7367 \\
-2.87\end{array}$ & \\
\hline Price & $\begin{array}{l}-2.2364 \\
-9.65\end{array}$ & & $\begin{array}{l}-1.8449 \\
-5.18\end{array}$ & & $\begin{array}{l}-1.4537 \\
-4.44\end{array}$ & \\
\hline Cigarettes Per Day & & $\begin{array}{l}0.0061 \\
42.76\end{array}$ & & $\begin{array}{l}0.0061 \\
12.97\end{array}$ & & $\begin{array}{l}0.0061 \\
13.02\end{array}$ \\
\hline $\begin{array}{l}\text { Real Per-Capita } \\
\text { Expenditure }\end{array}$ & $\begin{array}{l}-9.6096 \\
-2.15\end{array}$ & $\begin{array}{c}1.5427 \\
7.71\end{array}$ & $\begin{array}{c}0.6315 \\
0.12\end{array}$ & $\begin{array}{c}1.5395 \\
7.69\end{array}$ & $\begin{array}{c}1.2944 \\
0.26\end{array}$ & $\begin{array}{l}1.5211 \\
7.67\end{array}$ \\
\hline Private Worksite & $\begin{array}{c}-0.9187 \\
-8.32 \\
\end{array}$ & $\begin{array}{c}0.0104 \\
1.92\end{array}$ & $\begin{array}{c}-0.8896 \\
-7.34 \\
\end{array}$ & $\begin{array}{c}0.0106 \\
1.95\end{array}$ & & \\
\hline Health Facility & $\begin{array}{c}0.1501 \\
1.28\end{array}$ & $\begin{array}{c}0.0016 \\
0.29\end{array}$ & $\begin{array}{c}0.1950 \\
1.51\end{array}$ & $\begin{array}{c}0.0020 \\
0.36\end{array}$ & & \\
\hline Public Transportation & $\begin{array}{l}-0.4497 \\
-3.86\end{array}$ & $\begin{array}{c}0.0051 \\
0.95\end{array}$ & $\begin{array}{l}-0.4247 \\
-3.32\end{array}$ & $\begin{array}{c}0.0047 \\
0.88\end{array}$ & & \\
\hline Restaurants & $\begin{array}{c}0.1301 \\
1.06\end{array}$ & $\begin{array}{l}-0.0056 \\
-0.96\end{array}$ & $\begin{array}{c}0.1913 \\
1.41\end{array}$ & $\begin{array}{c}-0.0069 \\
-1.17\end{array}$ & & \\
\hline Grocery/Retail stores & $\begin{array}{c}0.6707 \\
5.19\end{array}$ & $\begin{array}{c}0.0070 \\
1.10\end{array}$ & $\begin{array}{c}0.6674 \\
4.62\end{array}$ & $\begin{array}{c}0.0080 \\
1.28\end{array}$ & & \\
\hline Shopping Malls & $\begin{array}{c}0.4581 \\
2.98\end{array}$ & $\begin{array}{l}-0.0086 \\
-1.21\end{array}$ & $\begin{array}{c}0.5750 \\
3.30\end{array}$ & $\begin{array}{l}-0.0081 \\
-1.14\end{array}$ & & \\
\hline $\begin{array}{l}\text { Clean Indoor } \\
\text { Air Index }\end{array}$ & & & & & $\begin{array}{c}-0.0358 \\
-2.10\end{array}$ & $\begin{array}{c}0.0022 \\
2.84\end{array}$ \\
\hline Photo ID 21 & & $\begin{array}{c}0.0427 \\
4.89\end{array}$ & & $\begin{array}{c}0.0400 \\
4.75\end{array}$ & & $\begin{array}{c}0.0320 \\
3.86\end{array}$ \\
\hline $\begin{array}{l}\text { Suspend/Revoke } \\
\text { License }\end{array}$ & & $\begin{array}{l}-0.0103 \\
-1.80\end{array}$ & & $\begin{array}{c}-0.0093 \\
-1.68\end{array}$ & & $\begin{array}{l}-0.0086 \\
-1.62\end{array}$ \\
\hline $\begin{array}{l}\text { Minimum Purchase } \\
\text { Age }\end{array}$ & & $\begin{array}{c}0.0020 \\
2.22\end{array}$ & & $\begin{array}{c}0.0019 \\
2.27\end{array}$ & & $\begin{array}{c}0.0015 \\
1.80\end{array}$ \\
\hline Purchase Law & & $\begin{array}{c}0.0063 \\
1.39\end{array}$ & & $\begin{array}{c}0.0071 \\
1.62\end{array}$ & & $\begin{array}{c}0.0103 \\
2.50\end{array}$ \\
\hline Use Law & & $\begin{array}{c}0.0173 \\
3.29\end{array}$ & & $\begin{array}{c}0.0195 \\
3.84\end{array}$ & & $\begin{array}{c}0.0215 \\
4.35\end{array}$ \\
\hline Possession Law & & $\begin{array}{c}0.0183 \\
3.80\end{array}$ & & $\begin{array}{c}0.0194 \\
4.18\end{array}$ & & $\begin{array}{c}0.0154 \\
3.33\end{array}$ \\
\hline Vending Machine & & $\begin{array}{l}0.0189 \\
0.85\end{array}$ & & $\begin{array}{c}0.0210 \\
0.99\end{array}$ & & $\begin{array}{c}0.0166 \\
0.78\end{array}$ \\
\hline State Authority & & $\begin{array}{c}0.0318 \\
7.07\end{array}$ & & $\begin{array}{c}0.0290 \\
6.62\end{array}$ & & $\begin{array}{c}0.0297 \\
6.95\end{array}$ \\
\hline New England & $\begin{array}{c}1.6205 \\
8.87\end{array}$ & $\begin{array}{c}0.0471 \\
5.54\end{array}$ & $\begin{array}{l}2.2168 \\
8.54\end{array}$ & $\begin{array}{c}0.0465 \\
5.40\end{array}$ & $\begin{array}{l}1.6818 \\
7.02\end{array}$ & $\begin{array}{c}0.0525 \\
6.50\end{array}$ \\
\hline Mid Atlantic & $\begin{array}{c}2.0288 \\
9.16\end{array}$ & $\begin{array}{c}0.0204 \\
1.72\end{array}$ & $\begin{array}{c}2.3706 \\
9.15\end{array}$ & $\begin{array}{c}0.0204 \\
1.73\end{array}$ & $\begin{array}{c}1.1538 \\
6.20\end{array}$ & $\begin{array}{c}0.0329 \\
3.77\end{array}$ \\
\hline
\end{tabular}




\begin{tabular}{|c|c|c|c|c|c|c|}
\hline \multirow[b]{3}{*}{ Variable } & \multirow{2}{*}{\multicolumn{2}{|c|}{$\begin{array}{c}\text { Ordinary Least Squares } \\
\text { Model } 1 \\
\end{array}$}} & \multirow{2}{*}{\multicolumn{2}{|c|}{$\begin{array}{c}\text { Three Stage Least Squares } \\
\text { Model } 2 \\
\end{array}$}} & \multirow{2}{*}{\multicolumn{2}{|c|}{$\begin{array}{c}\text { Three Stage Least Squares } \\
\text { Model } 3 \\
\end{array}$}} \\
\hline & & & & & & \\
\hline & $\begin{array}{l}\text { Conditional } \\
\text { Cigarette } \\
\text { Demand }\end{array}$ & $\begin{array}{c}\text { Physician } \\
\text { Advice }\end{array}$ & $\begin{array}{l}\text { Conditional } \\
\text { Cigarette } \\
\text { Demand }\end{array}$ & $\begin{array}{l}\text { Physician } \\
\text { Advice }\end{array}$ & $\begin{array}{l}\text { Conditional } \\
\text { Cigarette } \\
\text { Demand }\end{array}$ & $\begin{array}{c}\text { Physician } \\
\text { Advice }\end{array}$ \\
\hline East North Central & $\begin{array}{l}2.0782 \\
10.76\end{array}$ & $\begin{array}{c}0.0114 \\
1.28\end{array}$ & $\begin{array}{l}2.3563 \\
10.19\end{array}$ & $\begin{array}{l}0.0100 \\
1.11\end{array}$ & $\begin{array}{l}1.5721 \\
8.55\end{array}$ & $\begin{array}{c}0.0200 \\
2.69\end{array}$ \\
\hline West North Central & $\begin{array}{c}1.2713 \\
6.86\end{array}$ & $\begin{array}{c}-0.0562 \\
-6.30\end{array}$ & $\begin{array}{c}0.9223 \\
4.48\end{array}$ & $\begin{array}{l}-0.0582 \\
-6.49\end{array}$ & $\begin{array}{c}0.3934 \\
2.09\end{array}$ & $\begin{array}{l}-0.0537 \\
-6.45\end{array}$ \\
\hline South Atlantic & $\begin{array}{l}2.2987 \\
11.29\end{array}$ & $\begin{array}{l}-0.0054 \\
-0.57\end{array}$ & $\begin{array}{c}2.5502 \\
10.53\end{array}$ & $\begin{array}{l}-0.0052 \\
-0.55\end{array}$ & $\begin{array}{c}1.6845 \\
9.13\end{array}$ & $\begin{array}{c}0.0034 \\
0.47\end{array}$ \\
\hline East South Central & $\begin{array}{c}2.9240 \\
12.06\end{array}$ & $\begin{array}{l}-0.0370 \\
-3.31\end{array}$ & $\begin{array}{c}2.9584 \\
11.05\end{array}$ & $\begin{array}{c}-0.0362 \\
-3.20\end{array}$ & $\begin{array}{l}2.1081 \\
9.14\end{array}$ & $\begin{array}{l}-0.0290 \\
-3.01\end{array}$ \\
\hline West South Central & $\begin{array}{l}2.6319 \\
11.98\end{array}$ & $\begin{array}{l}-0.0545 \\
-5.26\end{array}$ & $\begin{array}{c}2.4139 \\
9.91\end{array}$ & $\begin{array}{l}-0.0540 \\
-5.19\end{array}$ & $\begin{array}{c}1.4092 \\
6.91\end{array}$ & $\begin{array}{l}-0.0438 \\
-5.11\end{array}$ \\
\hline Mountain & $\begin{array}{c}0.5601 \\
2.86\end{array}$ & $\begin{array}{l}-0.0178 \\
-1.98\end{array}$ & $\begin{array}{c}0.5768 \\
2.63\end{array}$ & $\begin{array}{l}-0.0188 \\
-2.08\end{array}$ & $\begin{array}{l}-0.0981 \\
-0.52\end{array}$ & $\begin{array}{l}-0.0113 \\
-1.42\end{array}$ \\
\hline May & $\begin{array}{c}0.1662 \\
1.88\end{array}$ & & $\begin{array}{c}0.2041 \\
2.09\end{array}$ & & $\begin{array}{c}0.2039 \\
2.10\end{array}$ & \\
\hline September & $\begin{array}{c}0.2931 \\
3.39\end{array}$ & & $\begin{array}{c}0.2943 \\
3.24\end{array}$ & & $\begin{array}{c}0.3079 \\
3.40\end{array}$ & \\
\hline $\begin{array}{l}\text { Education Less Than } \\
\text { High School }\end{array}$ & $\begin{array}{c}0.6740 \\
6.64\end{array}$ & & $\begin{array}{c}0.7426 \\
6.47\end{array}$ & & $\begin{array}{c}0.7509 \\
6.61\end{array}$ & \\
\hline $\begin{array}{l}\text { Education Some } \\
\text { College }\end{array}$ & $\begin{array}{l}-1.2410 \\
-13.29\end{array}$ & & $\begin{array}{l}-1.2851 \\
-13.05\end{array}$ & & $\begin{array}{l}-1.2726 \\
-12.97\end{array}$ & \\
\hline $\begin{array}{l}\text { Education at Least } \\
\text { College Degree }\end{array}$ & $\begin{array}{l}-3.5510 \\
-29.25\end{array}$ & & $\begin{array}{l}-3.7118 \\
-28.84\end{array}$ & & $\begin{array}{l}-3.7080 \\
-28.93\end{array}$ & \\
\hline Vocational School & $\begin{array}{l}-1.4004 \\
-7.69\end{array}$ & & $\begin{array}{c}-1.4164 \\
-7.28\end{array}$ & & $\begin{array}{l}-1.4191 \\
-7.33\end{array}$ & \\
\hline Real Family Income & $\begin{array}{l}-0.0016 \\
-5.63\end{array}$ & & $\begin{array}{l}-0.0017 \\
-5.62\end{array}$ & & $\begin{array}{l}-0.0016 \\
-5.44\end{array}$ & \\
\hline Metropolitan & $\begin{array}{l}-0.6425 \\
-7.47 \\
\end{array}$ & & $\begin{array}{c}-0.6440 \\
-6.43 \\
\end{array}$ & & $\begin{array}{c}-0.6253 \\
-6.37 \\
\end{array}$ & \\
\hline $\begin{array}{l}\text { Metropolitan Not } \\
\text { Identified }\end{array}$ & $\begin{array}{c}0.6369 \\
1.64\end{array}$ & & $\begin{array}{c}0.7581 \\
1.84\end{array}$ & & $\begin{array}{c}0.6835 \\
1.67\end{array}$ & \\
\hline Age & $\begin{array}{l}0.0439 \\
14.36\end{array}$ & & $\begin{array}{c}0.0518 \\
7.92\end{array}$ & & $\begin{array}{c}0.0522 \\
8.33\end{array}$ & \\
\hline $\begin{array}{l}\text { Married Spouse } \\
\text { Present }\end{array}$ & $\begin{array}{l}1.4510 \\
13.61\end{array}$ & & $\begin{array}{c}1.5850 \\
11.98\end{array}$ & & $\begin{array}{l}1.5983 \\
12.27\end{array}$ & \\
\hline Married Spouse Absent & $\begin{array}{c}2.6015 \\
6.83\end{array}$ & & $\begin{array}{c}2.7635 \\
6.86\end{array}$ & & $\begin{array}{c}2.7872 \\
6.94\end{array}$ & \\
\hline Widowed & $\begin{array}{c}0.0396 \\
0.21\end{array}$ & & $\begin{array}{l}-0.0035 \\
-0.02\end{array}$ & & $\begin{array}{c}-0.0003 \\
0.00\end{array}$ & \\
\hline Divorced & $\begin{array}{c}2.6877 \\
21.29\end{array}$ & & $\begin{array}{c}2.9074 \\
17.64\end{array}$ & & $\begin{array}{c}2.9266 \\
18.11\end{array}$ & \\
\hline Separated & $\begin{array}{c}2.5381 \\
13.16\end{array}$ & & $\begin{array}{c}2.7501 \\
12.02 \\
\end{array}$ & & $\begin{array}{c}2.7834 \\
12.34 \\
\end{array}$ & \\
\hline Male & $\begin{array}{l}3.6666 \\
49.45\end{array}$ & & $\begin{array}{l}3.7490 \\
36.26\end{array}$ & & $\begin{array}{l}3.7263 \\
36.99\end{array}$ & \\
\hline White Hispanic & $\begin{array}{l}-7.4470 \\
-40.01\end{array}$ & & $\begin{array}{l}-7.9300 \\
-30.62\end{array}$ & & $\begin{array}{l}-7.9624 \\
-31.42\end{array}$ & \\
\hline Black Hispanic & $\begin{array}{l}-7.3437 \\
-7.34\end{array}$ & & $\begin{array}{l}-7.6967 \\
-7.31\end{array}$ & & $\begin{array}{l}-7.5893 \\
-7.23\end{array}$ & \\
\hline
\end{tabular}




\begin{tabular}{|c|c|c|c|c|c|c|}
\hline \multirow[b]{3}{*}{ Variable } & \multirow{2}{*}{\multicolumn{2}{|c|}{$\begin{array}{c}\text { Ordinary Least Squares } \\
\text { Model } 1 \\
\end{array}$}} & \multirow{2}{*}{\multicolumn{2}{|c|}{$\begin{array}{c}\text { Three Stage Least Squares } \\
\text { Model } 2 \\
\end{array}$}} & \multirow{2}{*}{\multicolumn{2}{|c|}{$\begin{array}{c}\text { Three Stage Least Squares } \\
\text { Model } 3 \\
\end{array}$}} \\
\hline & & & & & & \\
\hline & $\begin{array}{l}\text { Conditional } \\
\text { Cigarette } \\
\text { Demand }\end{array}$ & $\begin{array}{l}\text { Physician } \\
\text { Advice }\end{array}$ & $\begin{array}{l}\text { Conditional } \\
\text { Cigarette } \\
\text { Demand }\end{array}$ & $\begin{array}{c}\text { Physician } \\
\text { Advice }\end{array}$ & $\begin{array}{l}\text { Conditional } \\
\text { Cigarette } \\
\text { Demand }\end{array}$ & $\begin{array}{c}\text { Physician } \\
\text { Advice }\end{array}$ \\
\hline Other Hispanic & $\begin{array}{l}-7.4276 \\
-8.63\end{array}$ & & $\begin{array}{l}-8.0198 \\
-8.50\end{array}$ & & $\begin{array}{l}-8.1314 \\
-8.67\end{array}$ & \\
\hline African American & $\begin{array}{l}-6.3580 \\
-49.27\end{array}$ & & $\begin{array}{l}-6.7597 \\
-39.46\end{array}$ & & $\begin{array}{l}-6.7673 \\
-40.22\end{array}$ & \\
\hline Native American & $\begin{array}{l}-2.6657 \\
-9.28\end{array}$ & & $\begin{array}{l}-2.8224 \\
-9.23\end{array}$ & & $\begin{array}{c}-2.8907 \\
-9.51\end{array}$ & \\
\hline Asian & $\begin{array}{l}-4.2443 \\
-14.18\end{array}$ & & $\begin{array}{l}-4.4145 \\
-13.83\end{array}$ & & $\begin{array}{l}-4.4503 \\
-14.11\end{array}$ & \\
\hline Other Race & $\begin{array}{l}-4.8990 \\
-2.29\end{array}$ & & $\begin{array}{l}-5.0930 \\
-2.26\end{array}$ & & $\begin{array}{l}-5.1205 \\
-2.28\end{array}$ & \\
\hline $\begin{array}{l}\text { Employed. But Did Not } \\
\text { Work }\end{array}$ & $\begin{array}{c}0.6389 \\
3.04\end{array}$ & & $\begin{array}{l}0.6969 \\
3.12\end{array}$ & & $\begin{array}{l}0.6987 \\
3.14\end{array}$ & \\
\hline Unemployed & $\begin{array}{c}0.7076 \\
4.38\end{array}$ & & $\begin{array}{l}0.7123 \\
4.18\end{array}$ & & $\begin{array}{l}0.7227 \\
4.25\end{array}$ & \\
\hline Not in Labor Force & $\begin{array}{l}0.1898 \\
2.07\end{array}$ & & $\begin{array}{c}0.2545 \\
2.31\end{array}$ & & $\begin{array}{l}0.2705 \\
2.49\end{array}$ & \\
\hline
\end{tabular}

All equations also include an intercept. Asymptotic t-ratios are in parentheses. The critical values for the t-ratios are 2.58 (2.33), 1.96 (1.64), $1.64(1.28)$ at the 1,5 , and $10 \%$ significance levels, respectively, based on a two-tailed (one-tailed) test. 
Table 3

First Stage Results

\begin{tabular}{|c|c|c|c|c|}
\hline & \multicolumn{2}{|c|}{ Model 2} & \multicolumn{2}{|c|}{ Model 3} \\
\hline Variable & $\begin{array}{c}\text { Conditional } \\
\text { Cigarette Demand }\end{array}$ & Physician Advice & $\begin{array}{c}\text { Conditional } \\
\text { Cigarette Demand }\end{array}$ & Physician Advice \\
\hline Price & $\begin{array}{c}-1.6225 \\
-6.63 \\
\end{array}$ & $\begin{array}{c}0.1043 \\
9.33\end{array}$ & $\begin{array}{c}-1.4244 \\
-5.99\end{array}$ & $\begin{array}{c}0.0991 \\
9.13\end{array}$ \\
\hline $\begin{array}{l}\text { Real Per-Capita } \\
\text { Expenditure }\end{array}$ & $\begin{array}{l}-8.8297 \\
-1.93\end{array}$ & $\begin{array}{c}0.8360 \\
4.01\end{array}$ & $\begin{array}{l}-7.1903 \\
-1.59\end{array}$ & $\begin{array}{c}0.8138 \\
3.93\end{array}$ \\
\hline Private Worksite & $\begin{array}{c}-0.9437 \\
-7.90\end{array}$ & $\begin{array}{c}0.0024 \\
0.43\end{array}$ & & \\
\hline Health Facility & $\begin{array}{c}0.1476 \\
1.18\end{array}$ & $\begin{array}{c}-0.0011 \\
-0.2\end{array}$ & & \\
\hline Public Transportation & $\begin{array}{l}-0.4245 \\
-3.54\end{array}$ & $\begin{array}{l}-0.0074 \\
-1.35\end{array}$ & & \\
\hline Restaurants & $\begin{array}{c}0.3338 \\
2.56\end{array}$ & $\begin{array}{c}0.0017 \\
0.29\end{array}$ & & \\
\hline Grocery/Retail stores & $\begin{array}{l}0.4913 \\
3.43\end{array}$ & $\begin{array}{l}-0.0085 \\
-1.29 \\
\end{array}$ & & \\
\hline Shopping Malls & $\begin{array}{c}0.5925 \\
3.73 \\
\end{array}$ & $\begin{array}{c}0.0084 \\
1.16 \\
\end{array}$ & & \\
\hline $\begin{array}{l}\text { Clean Indoor } \\
\text { Air Index }\end{array}$ & & & $\begin{array}{c}-0.0721 \\
-4.10\end{array}$ & $\begin{array}{l}-0.0009 \\
-1.13\end{array}$ \\
\hline May & $\begin{array}{l}0.2058 \\
2.30\end{array}$ & $\begin{array}{c}0.0139 \\
3.41\end{array}$ & $\begin{array}{l}0.2027 \\
2.27\end{array}$ & $\begin{array}{c}0.0140 \\
3.43\end{array}$ \\
\hline September & $\begin{array}{c}0.2874 \\
3.30\end{array}$ & $\begin{array}{l}-0.0015 \\
-0.37 \\
\end{array}$ & $\begin{array}{c}0.2983 \\
3.42\end{array}$ & $\begin{array}{c}-0.0016 \\
-0.41 \\
\end{array}$ \\
\hline $\begin{array}{l}\text { Education Less Than } \\
\text { High School }\end{array}$ & $\begin{array}{c}0.7314 \\
7.14\end{array}$ & $\begin{array}{c}0.0205 \\
4.38\end{array}$ & $\begin{array}{l}0.7339 \\
7.16\end{array}$ & $\begin{array}{c}0.0205 \\
4.39\end{array}$ \\
\hline $\begin{array}{l}\text { Education Some } \\
\text { College }\end{array}$ & $\begin{array}{l}-1.2329 \\
-13.09\end{array}$ & $\begin{array}{c}0.0031 \\
0.73\end{array}$ & $\begin{array}{l}-1.2282 \\
-13.03\end{array}$ & $\begin{array}{c}0.0031 \\
0.73\end{array}$ \\
\hline $\begin{array}{l}\text { Education at Least } \\
\text { College Degree }\end{array}$ & $\begin{array}{l}-3.5754 \\
-29.17 \\
\end{array}$ & $\begin{array}{c}-0.0052 \\
-0.93 \\
\end{array}$ & $\begin{array}{l}-3.5841 \\
-29.24 \\
\end{array}$ & $\begin{array}{c}-0.0051 \\
-0.91 \\
\end{array}$ \\
\hline Vocational School & $\begin{array}{l}-1.3450 \\
-7.32 \\
\end{array}$ & $\begin{array}{c}0.0159 \\
1.9 \\
\end{array}$ & $\begin{array}{c}-1.3589 \\
-7.39 \\
\end{array}$ & $\begin{array}{c}0.0159 \\
1.90\end{array}$ \\
\hline Real Family Income & $\begin{array}{l}-0.0016 \\
-5.63\end{array}$ & $\begin{array}{l}0.0000 \\
-0.09\end{array}$ & $\begin{array}{l}-0.0016 \\
-5.44\end{array}$ & $\begin{array}{l}0.0000 \\
-0.17\end{array}$ \\
\hline Metropolitan & $\begin{array}{l}-0.6135 \\
-7.00 \\
\end{array}$ & $\begin{array}{l}0.0225 \\
5.62\end{array}$ & $\begin{array}{c}-0.5850 \\
-6.70 \\
\end{array}$ & $\begin{array}{c}0.0221 \\
5.54\end{array}$ \\
\hline $\begin{array}{l}\text { Metropolitan Not } \\
\text { Identified }\end{array}$ & $\begin{array}{c}0.8708 \\
2.19 \\
\end{array}$ & $\begin{array}{c}0.0174 \\
0.96\end{array}$ & $\begin{array}{c}0.7780 \\
1.97 \\
\end{array}$ & $\begin{array}{c}0.0187 \\
1.04 \\
\end{array}$ \\
\hline Age & $\begin{array}{c}0.0517 \\
16.80 \\
\end{array}$ & $\begin{array}{c}0.0027 \\
19.19 \\
\end{array}$ & $\begin{array}{l}0.0516 \\
16.76 \\
\end{array}$ & $\begin{array}{c}0.0027 \\
19.17 \\
\end{array}$ \\
\hline $\begin{array}{l}\text { Married Spouse } \\
\text { Present }\end{array}$ & $\begin{array}{l}1.5503 \\
14.42\end{array}$ & $\begin{array}{c}0.0334 \\
6.81\end{array}$ & $\begin{array}{l}1.5536 \\
14.44\end{array}$ & $\begin{array}{c}0.0335 \\
6.83\end{array}$ \\
\hline $\begin{array}{l}\text { Married Spouse } \\
\text { Absent }\end{array}$ & $\begin{array}{c}2.6642 \\
6.93 \\
\end{array}$ & $\begin{array}{c}0.0180 \\
1.02 \\
\end{array}$ & $\begin{array}{c}2.6856 \\
6.98 \\
\end{array}$ & $\begin{array}{c}0.0182 \\
1.03 \\
\end{array}$ \\
\hline Widowed & $\begin{array}{c}-0.0177 \\
-0.09\end{array}$ & $\begin{array}{l}-0.0178 \\
-2.02\end{array}$ & $\begin{array}{c}-0.0140 \\
-0.07\end{array}$ & $\begin{array}{c}-0.0177 \\
-2.01\end{array}$ \\
\hline
\end{tabular}




\begin{tabular}{|c|c|c|c|c|}
\hline & \multicolumn{2}{|c|}{ Model 2} & \multicolumn{2}{|c|}{ Model 3} \\
\hline Variable & $\begin{array}{c}\text { Conditional } \\
\text { Cigarette Demand }\end{array}$ & Physician Advice & $\begin{array}{c}\text { Conditional } \\
\text { Cigarette Demand }\end{array}$ & Physician Advice \\
\hline Divorced & $\begin{array}{l}2.8294 \\
22.21\end{array}$ & $\begin{array}{c}0.0456 \\
7.85\end{array}$ & $\begin{array}{l}2.8372 \\
22.27\end{array}$ & $\begin{array}{c}0.0456 \\
7.84\end{array}$ \\
\hline Separated & $\begin{array}{c}2.6829 \\
13.79\end{array}$ & $\begin{array}{c}0.0507 \\
5.71\end{array}$ & $\begin{array}{c}2.6998 \\
13.87\end{array}$ & $\begin{array}{c}0.0507 \\
5.71\end{array}$ \\
\hline Male & $\begin{array}{c}3.5746 \\
47.80\end{array}$ & $\begin{array}{c}-0.0321 \\
-9.4\end{array}$ & $\begin{array}{c}3.5743 \\
47.78\end{array}$ & $\begin{array}{l}-0.0320 \\
-9.38\end{array}$ \\
\hline White Hispanic & $\begin{array}{l}-7.7133 \\
-40.93\end{array}$ & $\begin{array}{l}-0.0801 \\
-9.31\end{array}$ & $\begin{array}{l}-7.7418 \\
-41.10\end{array}$ & $\begin{array}{c}-0.0800 \\
-9.31\end{array}$ \\
\hline Black Hispanic & $\begin{array}{l}-7.4666 \\
-7.40\end{array}$ & $\begin{array}{l}-0.0158 \\
-0.34\end{array}$ & $\begin{array}{l}-7.4453 \\
-7.37\end{array}$ & $\begin{array}{l}-0.0156 \\
-0.34\end{array}$ \\
\hline Other Hispanic & $\begin{array}{l}-7.8058 \\
-8.99\end{array}$ & $\begin{array}{l}-0.1250 \\
-3.15\end{array}$ & $\begin{array}{l}-7.9112 \\
-9.11\end{array}$ & $\begin{array}{l}-0.1257 \\
-3.17\end{array}$ \\
\hline African American & $\begin{array}{l}-6.5326 \\
-49.94\end{array}$ & $\begin{array}{l}-0.0455 \\
-7.61\end{array}$ & $\begin{array}{l}-6.5377 \\
-50.01\end{array}$ & $\begin{array}{l}-0.0455 \\
-7.63\end{array}$ \\
\hline Native American & $\begin{array}{l}-2.7161 \\
-9.36\end{array}$ & $\begin{array}{l}-0.0224 \\
-1.69\end{array}$ & $\begin{array}{l}-2.7870 \\
-9.63\end{array}$ & $\begin{array}{l}-0.0234 \\
-1.77\end{array}$ \\
\hline Asian & $\begin{array}{l}-4.1997 \\
-13.81\end{array}$ & $\begin{array}{l}0.0301 \\
2.17\end{array}$ & $\begin{array}{l}-4.2215 \\
-13.95 \\
\end{array}$ & $\begin{array}{c}0.0270 \\
1.95\end{array}$ \\
\hline Other Race & $\begin{array}{l}-4.8036 \\
-2.23\end{array}$ & $\begin{array}{c}0.0445 \\
0.45\end{array}$ & $\begin{array}{l}-4.8230 \\
-2.23\end{array}$ & $\begin{array}{c}0.0437 \\
0.44\end{array}$ \\
\hline $\begin{array}{l}\text { Employed. But Did } \\
\text { Not Work }\end{array}$ & $\begin{array}{c}0.6886 \\
3.25\end{array}$ & $\begin{array}{c}0.0166 \\
1.72\end{array}$ & $\begin{array}{c}0.6877 \\
3.24\end{array}$ & $\begin{array}{c}0.0164 \\
1.70\end{array}$ \\
\hline Unemployed & $\begin{array}{c}0.6810 \\
4.18\end{array}$ & $\begin{array}{l}-0.0070 \\
-0.94\end{array}$ & $\begin{array}{c}0.6983 \\
4.29\end{array}$ & $\begin{array}{c}-0.0073 \\
-0.98\end{array}$ \\
\hline Not in Labor Force & $\begin{array}{c}0.2645 \\
2.85\end{array}$ & $\begin{array}{c}0.0254 \\
6\end{array}$ & $\begin{array}{c}0.2715 \\
2.93\end{array}$ & $\begin{array}{c}0.0252 \\
5.97\end{array}$ \\
\hline New England & $\begin{array}{l}1.9594 \\
10.16\end{array}$ & $\begin{array}{c}0.0786 \\
8.93\end{array}$ & $\begin{array}{c}1.4093 \\
7.79\end{array}$ & $\begin{array}{c}0.0765 \\
9.27\end{array}$ \\
\hline Mid Atlantic & $\begin{array}{c}2.2165 \\
8.33\end{array}$ & $\begin{array}{c}0.0483 \\
3.98\end{array}$ & $\begin{array}{c}0.8450 \\
4.24\end{array}$ & $\begin{array}{c}0.0466 \\
5.12\end{array}$ \\
\hline East North Central & $\begin{array}{c}2.3750 \\
11.66\end{array}$ & $\begin{array}{c}0.0472 \\
5.07\end{array}$ & $\begin{array}{c}1.5075 \\
8.97\end{array}$ & $\begin{array}{c}0.0406 \\
5.29\end{array}$ \\
\hline West North Central & $\begin{array}{c}1.4392 \\
6.97\end{array}$ & $\begin{array}{c}-0.0142 \\
-1.5\end{array}$ & $\begin{array}{c}0.9195 \\
4.81\end{array}$ & $\begin{array}{l}-0.0173 \\
-1.98\end{array}$ \\
\hline South Atlantic & $\begin{array}{l}2.5389 \\
11.52\end{array}$ & $\begin{array}{c}0.0379 \\
3.77\end{array}$ & $\begin{array}{l}1.5504 \\
9.15\end{array}$ & $\begin{array}{c}0.0336 \\
4.35\end{array}$ \\
\hline East South Central & $\begin{array}{l}3.0688 \\
12.03\end{array}$ & $\begin{array}{c}0.0058 \\
0.5\end{array}$ & $\begin{array}{c}2.0567 \\
9.38\end{array}$ & $\begin{array}{c}0.0046 \\
0.46\end{array}$ \\
\hline West South Central & $\begin{array}{l}2.6497 \\
11.43\end{array}$ & $\begin{array}{c}-0.0244 \\
-2.3\end{array}$ & $\begin{array}{l}1.4537 \\
7.56\end{array}$ & $\begin{array}{l}-0.0277 \\
-3.15\end{array}$ \\
\hline Mountain & $\begin{array}{c}0.7786 \\
3.75\end{array}$ & $\begin{array}{c}0.0159 \\
1.68\end{array}$ & $\begin{array}{c}0.0176 \\
0.10\end{array}$ & $\begin{array}{c}0.0104 \\
1.26\end{array}$ \\
\hline Photo ID 21 & $\begin{array}{l}-0.0462 \\
-0.24\end{array}$ & $\begin{array}{c}0.0323 \\
3.66\end{array}$ & $\begin{array}{c}0.2884 \\
1.52\end{array}$ & $\begin{array}{c}0.0328 \\
3.80\end{array}$ \\
\hline $\begin{array}{l}\text { Suspend/Revoke } \\
\text { License }\end{array}$ & $\begin{array}{l}-0.0326 \\
-0.25\end{array}$ & $\begin{array}{l}-0.0148 \\
-2.54\end{array}$ & $\begin{array}{c}0.0664 \\
0.54\end{array}$ & $\begin{array}{l}-0.0154 \\
-2.76\end{array}$ \\
\hline $\begin{array}{l}\text { Minimum Purchase } \\
\text { Age }\end{array}$ & $\begin{array}{l}-0.0095 \\
-0.49\end{array}$ & $\begin{array}{c}0.0012 \\
1.38\end{array}$ & $\begin{array}{c}0.0056 \\
0.29\end{array}$ & $\begin{array}{c}0.0012 \\
1.32\end{array}$ \\
\hline Purchase Law & $\begin{array}{l}-0.1023 \\
-1.01\end{array}$ & $\begin{array}{c}0.0038 \\
0.83\end{array}$ & $\begin{array}{l}-0.2410 \\
-2.56\end{array}$ & $\begin{array}{c}0.0050 \\
1.16\end{array}$ \\
\hline Use Law & $\begin{array}{l}-0.2789 \\
-2.40\end{array}$ & $\begin{array}{c}0.0123 \\
2.32\end{array}$ & $\begin{array}{c}-0.4464 \\
-3.97\end{array}$ & $\begin{array}{c}0.0131 \\
2.56\end{array}$ \\
\hline
\end{tabular}




\begin{tabular}{|l|c|c|c|c|}
\hline & \multicolumn{2}{|c|}{ Model 2 } & \multicolumn{2}{c|}{ Model 3 } \\
\hline Variable & $\begin{array}{c}\text { Conditional } \\
\text { Cigarette Demand }\end{array}$ & Physician Advice & $\begin{array}{c}\text { Conditional } \\
\text { Cigarette Demand }\end{array}$ & Physician Advice \\
\hline Possession Law & -0.2004 & 0.0159 & 0.0297 & 0.0148 \\
& -1.85 & 3.21 & 0.28 & 3.02 \\
\hline Vending Machine & -0.2685 & 0.0333 & 0.0500 & 0.0322 \\
& -0.55 & 1.49 & 0.10 & 1.45 \\
\hline State Authority & 0.0457 & 0.0303 & -0.0144 & 0.0317 \\
& 0.46 & 6.69 & -0.15 & 7.17 \\
\hline Constant & 14.6259 & 0.2010 & 15.1316 & 0.2079 \\
& 27.82 & 8.38 & 29.85 & 8.99 \\
\hline
\end{tabular}

All equations also include an intercept. Asymptotic t-ratios are in parentheses. The critical values for the t-ratios are $2.58(2.33), 1.96(1.64), 1.64(1.28)$ at the 1,5 , and $10 \%$ significance levels, respectively, based on a two-tailed (one-tailed) test. 